\title{
Toward a Multibiomarker Panel to Optimize Outcome and Predict Response in Juvenile Idiopathic Arthritis
}

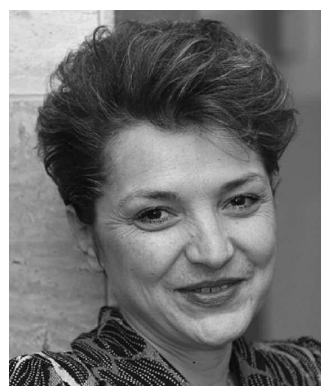

Juvenile idiopathic arthritis (JIA) is a complex disease with heterogeneous pathogenesis, autoinflammatory and autoimmune, involving both innate and adaptive immunity. All JIA subtypes display joint inflammation, but with distinct clinical phenotypes, disease courses, outcomes, and response to different treatment approaches ${ }^{1}$. In the last decade, much attention was focused on discovery and potential use of different biomarkers that could provide support in diagnostic and prognostic evaluations. In the sense of diagnostics and personalized therapy decisions, biomarkers could play a major role to support initial diagnosis, allow disease monitoring, and possibly indicate the reoccurrence of inflammatory responses even before clinical manifestation. Such a candidate biomarker(s) should be validated and proven as highly sensitive, obtained by standardized methodology and evaluable in everyday clinical practice. Two reviews by Swart, et $a l^{2}$ and Gohar, et $a l^{3}$ exhaustingly elaborated current knowledge and possible clinical usage of different biomarkers in JIA, pointing out applicability of S100 proteins.

The phagocyte-specific S100 proteins (calgranulins) S100A8 (calgranulin A, also referred to as myeloid-related protein, MRP8), S100A9 (calgranulin B, MRP14), and S100A12 (calgranulin C) are calcium-binding proteins and phagocyte activation markers acting as proinflammatory ligands of Toll-like receptor-4 (TLR-4), which are constitutively expressed predominantly in phagocytic myeloid cells (i.e., granulocytes and monocytes) ${ }^{4}$. S100 proteins (S100A8/A9 and S100A12) have been studied extensively in JIA and other inflammatory diseases and have been found to correlate with inflammatory indices, including C-reactive protein (CRP) and erythrocyte sedimentation rate (ESR) ${ }^{5}$. Synovial fluid concentrations of these proteins in the inflamed joints correlate and are about 10- to 20 -fold higher compared to the serum levels ${ }^{6}$. MRP8/14 protein complex (also known as calprotectin) has been shown to be useful for diagnosing systemic-onset JIA. Serum MRP8/14 concentra- tions in patients with active systemic JIA were found to be higher than in healthy controls, patients with systemic infections, and patients with autoinflammatory chronic infantile neurological cutaneous and auricular syndrome (44-, 6-, and 5 -fold higher, respectively) ${ }^{7}$. MRP8/14 serum concentrations can also be used to detect subclinical inflammatory activity and predict relapse of the disease after therapy withdrawal in systemic JIA ${ }^{8}$.

The levels of circulating S100A8/A9 and S100A12 in patients with nonsystemic JIA are clearly not as high as those in patients with systemic JIA, but their possible role as immune biomarkers for (subclinical) disease activity is promising in both JIA patient groups. Both S100A8/A9 and S100A12 are validated predictors of relapse risk and disease activity in JIA ${ }^{9,10}$. Interestingly, S100A12 concentration measured at the time of treatment withdrawal in patients with JIA predicted the development of flare better than MRP8/14, while the combination of S100A12 plus high-sensitivity (hs)CRP had the best prediction potential ${ }^{11}$. Details about studies performed in nonsystemic JIA are presented in Table 1.

In this issue of The Journal, Gohar, et al ${ }^{12}$ present results of the S100A12 concentrations (measured by commercial and in-house method) in patients with nonsystemic JIA from 3 prospective cohort studies [UK Childhood Arthritis Response to Medication Study for MTX treatment, and the Dutch Arthritis and Biologicals in Children Register and the German Registry for Biologics in Paediatric Rheumatology for anti-tumor necrosis factor (TNF) treatment]. In the Gohar, et al study, baseline serum S100A12 was found to be associated with response to both MTX and anti-TNF therapy in patients with JIA who have had a high baseline concentration that decreased significantly with either MTX or anti-TNF treatment ${ }^{12}$. Patients with higher baseline S100A12 concentration had higher disease activity and ESR and were more likely to be treatment responders. Addition of S100A12 to multivariate model analysis improved the

See S100A12 and response in JIA, page 547

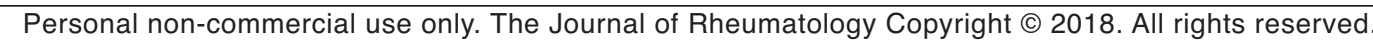


Table 1. Evidence of S100A8/A9 and S100A12 biomarker capabilities in nonsystemic JIA.

\begin{tabular}{|c|c|}
\hline Frosch, et $a l^{5}$ & $\begin{array}{l}\text { MRP } 8 / 14 \text { concentrations in the synovial fluid of inflamed joints are about } 10 \text { - to } 20 \text {-fold higher } \\
\text { compared to the serum levels with a correlation between these } 2 \text { levels. Serum concentrations of } \\
\text { MRP } / 14 \text { correlated with the state of disease activity or remission in patients with oligoarticular } \\
\text { JIA treated with IA steroids. }\end{array}$ \\
\hline Foell, et $a l^{6}$ & $\begin{array}{l}\text { Clear difference between S100A12 serum concentrations in oligoarticular or polyarticular JIA and } \\
\text { those with systemic JIA. Remarkable elevation of S100A12 serum concentrations in samples } \\
\text { obtained from patients with JIA experiencing a relapse of their arthritis during the following weeks. }\end{array}$ \\
\hline Foell, et al ${ }^{10}$ & $\begin{array}{l}\text { After MTX treatment discontinuation, MRP8/14 levels during remission were significantly higher } \\
\text { in patients who subsequently developed flares compared with patients maintaining stable remission. } \\
\text { Higher MRP8/14 concentrations were associated with risk of relapse after discontinuing MTX. }\end{array}$ \\
\hline Moncrieffe, et al ${ }^{16}$ & $\begin{array}{l}\text { High levels of baseline serum MRP } 8 / 14 \text { have prognostic value in predicting a subgroup of patients } \\
\text { whose arthritis will improve with MTX. }\end{array}$ \\
\hline Anink, et $a l^{17}$ & $\begin{array}{l}\text { High levels of baseline MRP } 8 / 14 \text { are associated with good response to anti-TNF treatment, whereas } \\
\text { elevated MRP8/14 levels at discontinuation of anti-TNF were associated with higher chance to } \\
\text { flare in patients with JIA. }\end{array}$ \\
\hline Kahn, et $a l^{18}$ & $\begin{array}{l}\text { In nonsystemic JIA patients who fail MTX and need anti-TNF therapy, baseline MRP8/14 levels } \\
\text { are found to be higher in responders compared to nonresponders, while after start of treatment the } \\
\text { MRP8/14 levels decrease only in responders. }\end{array}$ \\
\hline Gerss, et $a l^{11}$ & $\begin{array}{l}\text { S100A12 and MRP } 8 / 14 \text { are especially useful in predicting early flares within } 3 \text { months after } \\
\text { treatment withdrawal, and predictive performance of the marker S100A12 and MRP8/14 was } \\
\text { improved by adding hsCRP. }\end{array}$ \\
\hline Rothmund, et $a l^{9}$ & $\begin{array}{l}\text { Biomarkers MRP8/14 and S100A12 assays that are available for routine practice are validated to } \\
\text { be used for the prediction of JIA relapse after stopping medication. }\end{array}$ \\
\hline Yamasaki, et al ${ }^{19}$ & $\begin{array}{l}\text { Patients with JIA who stopped anti-TNF treatment flared within } 6 \text { months after treatment discon- } \\
\text { tinuation if they have had significantly higher MRP } 8 / 14 \text { levels compared to patients with stable } \\
\text { remission. }\end{array}$ \\
\hline
\end{tabular}

JIA: juvenile idiopathic arthritis; MRP: myeloid-related protein; IA: intraarticular; MTX: methotrexate; TNF: tumor necrosis factor; hsCRP: high-sensitivity C-reactive protein.

prediction of response to treatment. In-house ELISA method assay was comparable with the commercial assay, but was found to be slightly more sensitive.

No single biomarker can be sufficiently sensitive or specific for predicting response ${ }^{13}$, especially in a heterogeneous disease such as JIA, which can follow an oligoarticular or polyarticular pattern emerging for different treatment strategies. The best proven candidates for multibiomarker panel in nonsystemic JIA at the moment are S100A8/A9, S100A12, hsCRP, and antinuclear antibody. S100 proteins are involved in the amplification of the inflammatory process and are present in the crucial sites of joint destruction, in the synovial membrane and the cartilagepannus junction ${ }^{14}$. So the extent of clinically or subclinically affected joints probably affects sensitivity of these biomarkers in nonsystemic JIA subtypes. That is why it would be rational to focus further efforts toward development and validation of separate multibiomarker panels for the oligoarticular and polyarticular JIA course, with specific cutoffs. A recently published longitudinal study of patients with established rheumatoid arthritis in whom calprotectin (S100A8/A9) was shown to have the strongest association with ultrasound-detected synovitis and predicts response to biologic treatment ${ }^{15}$ provides the rationale for involvement of ultrasound in the clinically meaningful prediction panel for oligoarticular and polyarticular JIA courses. Therefore, longitudinal study of JIA patients with regular followup visits using a multibiomarker panel combined with imaging (i.e., ultrasound) is planned by the Outcome Measures in Rheumatology Clinical Trials (OMERACT) pediatric ultrasound group.

JELENA VOJINOVIC, $M D, P h D$ University of Nis, Faculty of Medicine, Department of Pediatric Rheumatology, Nis, Serbia.

Address correspondence to Prof. Dr. J. Vojinovic, University of Nis, Faculty of Medicine, Department of Pediatric Rheumatology, Bul dr Zorana Djindjica, 81 Nis, 18000 Serbia.E-mail: vojinovic.jelena@gmail

\section{REFERENCES}

1. Ravelli A, Martini A. Juvenile idiopathic arthritis. Lancet 2007;369:767-78.

2. Swart JF, de Roock S, Prakken BJ. Understanding inflammation in juvenile idiopathic arthritis: How immune biomarkers guide clinical strategies in the systemic onset subtype. Eur J Immunol 2016;46:2068-77.

3. Gohar F, Kessel C, Lavric M, Holzinger D, Foell D. Review of biomarkers in systemic juvenile idiopathic arthritis: helpful tools or just playing tricks? Arthritis Res Ther 2016;18:163.

4. Kessel C, Holzinger D, Foell D. Phagocyte-derived S100 proteins in autoinflammation: Putative role in pathogenesis and usefulness as biomarkers. Clin Immunol 2013;147:229-41.

5. Frosch M, Strey A, Vogl T, Wulffraat NM, Kuis W, Sunderkötter C, et al. Myeloid-related proteins 8 and 14 are specifically secreted during interaction of phagocytes and activated endothelium and are useful markers for monitoring disease activity in 
pauciarticular-onset juvenile rheumatoid arthritis. Arthritis Rheum 2000;43:628-37.

6. Foell D, Wittkowski H, Hammerschmidt I, Wulffraat N, Schmeling $\mathrm{H}$, Frosch $\mathrm{M}$, et al. Monitoring neutrophil activation in juvenile rheumatoid arthritis by S100A12 serum concentrations. Arthritis Rheum 2004;50:1286-95.

7. Frosch M, Ahlmann M, Vogl T, Wittkowski H, Wulffraat N, Foell D, et al. The myeloid-related proteins 8 and 14 complex, a novel ligand of toll-like receptor 4 , and interleukin- $1 \beta$ form a positive feedback mechanism in systemic-onset juvenile idiopathic arthritis. Arthritis Rheum 2009;60:883-91.

8. Holzinger D, Frosch M, Kastrup A, Prince FH, Otten MH, Van Suijlekom-Smit LW, et al. The Toll-like receptor 4 agonist MRP8/14 protein complex is a sensitive indicator for disease activity and predicts relapses in systemic-onset juvenile idiopathic arthritis. Ann Rheum Dis 2012;71:974-80.

9. Rothmund F, Gerss J, Ruperto N, Däbritz J, Wittkowski H, Frosch $\mathrm{M}$, et al. Validation of relapse risk biomarkers for routine use in patients with juvenile idiopathic arthritis. Arthritis Care Res 2013;66:949-55.

10. Foell D, Wulffraat N, Wedderburn LR, Wittkowski H, Frosch M, Gerss J, et al. Methotrexate withdrawal at 6 vs 12 months in juvenile idiopathic arthritis in remission: a randomized clinical trial. JAMA 2010;303:1266-73.

11. Gerss J, Roth J, Holzinger D, Ruperto N, Wittkowski H, Frosch M, et al. Phagocyte-specific S100 proteins and high-sensitivity C reactive protein as biomarkers for a risk-adapted treatment to maintain remission in juvenile idiopathic arthritis: a comparative study. Ann Rheum Dis 2012;71:1991-7.

12. Gohar F, Anink J, Moncrieffe H, Van Suijlekom-Smit LW, Prince FH, van Rossum MA, et al. S100A12 is associated with response to therapy in juvenile idiopathic arthritis. J Rheumatol 2018; 45:547-54.
13. Centola M, Cavet G, Shen Y, Ramanujan S, Knowlton N, Swan KA, et al. Development of a multibiomarker disease activity test for rheumatoid arthritis. PLoS One 2013;8:e60635.

14. Schelbergen RF, Blom AB, van den Bosch MH, Slöetjes A, Abdollahi-Roodsaz S, Schreurs BW, et al. Alarmins S100A8 and S100A9 elicit a catabolic effect in human osteoarthritic chondrocytes that is dependent on Toll-like receptor 4. Arthritis Rheum 2012;64:1477-87.

15. Nordal HH, Brokstad KA, Solheim M, Halse AK, Kvien TK, Hammer HB. Calprotectin (S100A8/A9) has the strongest association with ultrasound-detected synovitis and predicts response to biologic treatment: results from a longitudinal study of patients with established rheumatoid arthritis. Arthritis Res Ther 2017;19:3.

16. Moncrieffe H, Ursu S, Holzinger D, Patrick F, Kassoumeri L, Wade A, et al. A subgroup of juvenile idiopathic arthritis patients who respond well to methotrexate are identified by the serum biomarker MRP8/14 protein. Rheumatology 2013;52:1467-76.

17. Anink J, Van Suijlekom-Smit LW, Otten MH, Prince FH, van Rossum MA, Dolman KM, et al. MRP8/14 serum levels as a predictor of response to starting and stopping anti-TNF treatment in juvenile idiopathic arthritis. Arthritis Res Ther 2015;17:200.

18. Kahn R, Berthold E, Gullstrand B, Schmidt T, Kahn F, Geborek P, et al. Circulating complexes between tumour necrosis factor-alpha and etanercept predict long-term efficacy of etanercept in juvenile idiopathic arthritis. Acta Paediatr 2016;105:427-32.

19. Yamasaki Y, Takei S, Imanaka H, Nerome Y, Kubota T, Nonaka Y, et al. Prediction of long-term remission of oligo/polyarticular juvenile idiopathic arthritis with S100A12 and vascular endothelial growth factor. Mod Rheumatol 2015;7595:1-23.

J Rheumatol 2018;45:451-3; doi:10.3899/jrheum.180036 